\title{
Integrated Management of Mouldy Core and Pink Mould Rot of Apples in Storage under Controlled Atmosphere Conditions
}

\author{
Neelam Kumari ${ }^{1^{*}}$, J. N. Sharma² and Deepika Singh \\ ${ }^{1,2}$ Dept. of Plant Pathology, ${ }^{3}$ Dept. of Fruit Science, Dr. Y. S. Parmar University of Horticulture and Forestry, Nauni, Solan, \\ H.P. (173 230), India
}

\section{Corresponding Author}

Neelam Kumari

e-mail: neelkumari90@gmail.com

\author{
Article History \\ Article ID: IJEP0389 \\ Received in $30^{\text {th }}$ September, 2020 \\ Received in revised form $05^{\text {th }}$ November, 2020 \\ Accepted in final form $20^{\text {th }}$ November, 2020
}

\begin{abstract}
Effect of pre-cooling, hot water treatment, fumigation, an antagonist (Bacillus subtilis) along with treatment of apple fruits with extract of Emblica officinalis (amla) and coating with neem oil was evaluated for their activity against the fungal growth of Alternaria alternata and Trichothecium roseum, the causal agents of mouldy core and pink mould rot, respectively. Impregnation of fruit trays with botanical formulations was also integrated with other treatments before placing the treated and untreated fruits in controlled atmosphere (CA) storage for four months. The integration of hydro cooling with ice water $+\mathrm{CaCl}_{2}$ (HIWC)+fruit skin coating with neem oil (1\%)+placing treated fruits on botanical formulation (BF) impregnated fruit trays (treatment combination $\mathrm{T}_{7}$ ) prior to CA storage gave highest inhibition of the pathogenic tested fungi with rot incidence of $16.05,20.46 \%$ and fruit rot of $9.05,11.46 \%$, respectively. The treatment combination $\mathrm{T}_{6}$ in which the antagonist $B$. subtilis was integrated with pre-cooling and BF-impregnated trays was the next effective treatment with rot incidence of $20.35,23.07 \%$ and fruit rot of $13.34,17.08 \%$, respectively.
\end{abstract}

Keywords: Botanical formulation, CA storage, fumigation, pre-cooling

\section{Introduction}

Apple (Malusxdomestica Borkh.) is a member of Rosaceae family and considered as one of the most economically important fruit trees of temperate zones (Martinelli et al., 2008). Agro-climatic conditions in hilly regions of Himachal Pradesh offer immense natural potential for increasing area and production under temperate fruits, especially apple. Though the area and production under apple cultivation in Himachal Pradesh has increased during the last few decades, but the productivity per unit area has not increased proportionally and is quite low as compared to the advanced apple growing countries of the world. The reasons for low apple productivity could be many, but one of them is the post harvest losses caused by different fungi. More recently, a new problem of mouldy core rot associated with pink mould rot has been encountered in major fruit growing areas of Shimla and Kullu districts of Himachal Pradesh (Gupta and Sharma, 2008). Preliminary studies have indicated the association of several fungi involved in mouldy core and core rot of dropped as well as fully mature apple fruit on the trees, but Alternaria alternata is the predominant fungal pathogen responsible for mouldy core and core rot of apple in different regions of the world (Reuveni and Sheglov, 2002). Mouldy core is characterized by presence of fungal mycelium within the fruit core without visible penetration in to the flesh of the fruits. However, when invasive penetration of mycelium in the flesh of the fruit was present, it caused wet rot type of symptom and the disease is said to be a core rot. Fruits brought from lower altitude of the Shimla district showed the dry rot symptom characterized by drying of infected tissue. Similar symptoms were reported by Kaul (1979), Niem et al. (2007) and Shtienberg (2012). First symptoms of pink mould rot on apples caused by Trichothecium roseum were reported as water soaked appearance of the infected tissue which later produced a mass of powdery pink coloured spores (Kwon et al., 2014).

There are several strategies available for the management of post harvest losses. Among these, better post harvest handling practices and use of pre and post harvest fungicides are the major management strategies. However, use of fungicides in the management of post harvest diseases poses risk of residue. Use of chemicals in the management of post harvest diseases is also restricted due to their possible carcinogenicity, teratogenicity, acute toxicity, long degradation periods, environment pollution and their effects on human health. On the other hand, bio-chemicals derived from extracts of 
the plants or other bio-resources have no toxic effects and their use is gaining grounds as an alternative to the prevalent chemical control measures. Thus there is great scope to improve post harvest management practices for increasing the storability of the apple produced.

\section{Materials and Methods}

\subsection{Fruit}

Starking Delicious varieties of apples were harvested at the preclimacteric stage from a commercial orchard in Shimla district of Himachal Pradesh. The climacteric rise in carbon dioxide production had not yet begun. The apples were randomized prior to treatment.

\subsection{Isolation and identification of causal fungi}

The isolates used during the study were previously isolated from decayed apples in storage. The diseased fruits were surface sterilized with absolute alcohol under aseptic conditions. Small bits of 1 to $2 \mathrm{~mm}$ size were taken from junction of diseased and healthy part of fruit with the help of sterilized sharp blade and scalpel. These bits were surface sterilized with sodium hypochlorite (1.0\%) for 10 to 20 seconds and washed thrice with sterilized distilled water under aseptic conditions. The bits were then placed on the sterilized filter paper to remove the excess moisture and subsequently transferred to sterilized Petri plates containing potato dextrose agar (PDA) medium. The inoculated Petri plates were incubated at $25 \pm 1^{\circ} \mathrm{C}$ in BOD incubator and examined daily for mycelial growth. The fungal growth developed in Petri plates was purified by hyphal tip technique and was further cultured on slants containing PDA. These slants of culture were preserved at $5^{\circ} \mathrm{C}$ in the refrigerator for further studies. Stock cultures were maintained by regularly sub-culturing after 20 to 25 days. The conidial suspensions $\left(1 \times 10^{4}\right.$ conidia $\left.\mathrm{ml}^{-1}\right)$ used for fruit inoculations were prepared from 10-day old cultures. The isolated fungi were identified using authentic descriptions in literature (Marie-Jose et al., 2004; Al-Hindi, 2011; Jurick, 2014; Hamid et al., 2014; Vico et al., 2014).

\subsection{Fruit inoculation and treatments}

\subsubsection{Fruit inoculation}

Fruits were inoculated following Well method of Granger and Horne (1924). Wells were made on the fruit surface with the help of cork borer (internal diameter $5 \mathrm{~mm}$ ). The inoculum of A. alternata or T. roseum was placed at the bottom of wells and plugged back. These were further sealed with sterile paraffin wax.

\subsubsection{Treatments}

After inoculation, inoculated apples were subjected to different treatments as described below:

$\mathrm{T}_{1}$. Hydro-cooling with ice water and $\mathrm{CaCl}_{2}(\mathrm{HIWC})+\mathrm{Hot}$ water treatment $\left(50^{\circ} \mathrm{C}\right)$

$\mathrm{T}_{2} \cdot \mathrm{T}_{1}+$ Plant extract (Emblica officinalis)

\section{$\mathrm{T}_{3} \cdot \mathrm{T}_{1}+$ Antagonist (Bacillus subtilis)}

$\mathrm{T}_{4}$. HIWC + Antagonist (Bacillus subtilis)+1-Methylcyclopropene (1-MCP) fumigation

$T_{5}$. Skin coating with neem oil $(1 \%)+$ Botanical formulation impregnated trays

$\mathrm{T}_{6}$. HIWC + Antagonist (Bacillus subtilis)+Botanical formulation impregnated trays

$\mathrm{T}_{7}$. HIWC+Skin coating with neem oil $(1 \%)+$ Botanical formulation impregnated trays

$\mathrm{T}_{8}$. Apples untreated+Botanical formulation impregnated trays $\mathrm{T}_{9}$. Control (Untreated)

Each treatment was replicated thrice with each replicate containing five fruits for a particular test pathogen. Both treated and untreated fruits were then stored in controlled atmosphere $\left(1 \pm 0.5^{\circ} \mathrm{C}\right.$ temperature, 87 to $92 \% \mathrm{RH}, 1.4 \%$ carbon dioxide and $1.2 \%$ oxygen concentration) conditions and evaluated for rot incidence and fruit rot after 4 months of storage.

Rot incidence (\%) was calculated by the formula given below:

Disease incidence $(\%)=$ No.of diseased fruits/Total no.of fruits $\times 100$

Fruit rot (\%) was calculated by the formula given by Srivastava and Tandon (1968):

Fruit rot $(\%)=(\mathrm{W}-\mathrm{w}) / \mathrm{W} \times 100$

Where,

$W=$ Weight of the fruits before inoculation

$\mathrm{W}=$ Weight of the fruits after removal of the rotten tissue

\subsubsection{Hydro-cooling with ice water and $\mathrm{CaCl}_{2}$ (HIWC)}

Healthy apple fruits were harvested early morning during the months of July and August. To see the effect of pre-cooling on post harvest rotting of apples, harvested fruits were subjected to hydro-cooling with ice water $+\mathrm{CaCl}_{2}(2 \% \mathrm{w} / \mathrm{w})$ for $30 \mathrm{~min}$. Fruits were then inoculated with isolated fungi and transferred to CA storage.

\subsubsection{Hot water treatment (HWT)}

Hot water dip treatments were performed in a thermostatically controlled water bath. Inoculated apples were subjected to hot water treatment at $50^{\circ} \mathrm{C}$ for 3 minutes and then moved to CA storage.

\subsubsection{Plant extract}

Plant extract used was of amla (Emblica officinalis). Fresh leaves (200 g) of amla were taken and then washed under tap water and ground for 5 minutes in a blender by adding small quantity of sterilized warm distilled water. After grinding, $200 \mathrm{ml}$ distilled water was added and homogenized in orbital shaker at $2000 \mathrm{rpm}$ for half an hour to get $100 \%$ extract of plant parts. The plant material was then filtered through doublelayered muslin cloth. Sterilization of the extracts was done in autoclave at 5 psi pressure for one hour for three consecutive 
days and then the extracts were kept in a refrigerator for further use. Inoculated apples were subjected to dipping in E. officinalis extract at $10 \%$ concentration for $5 \mathrm{~min}$ and then stored in CA conditions.

\subsubsection{Antagonist}

The antagonist used was the bacterium Bacillus subtilis isolated from neglected apple orchards with minimal or no pesticide spray history. After 12 hours, inoculated apples were dipped in $B$. subtilis inoculum. The inoculum was prepared and adjusted to the concentration of $10^{8} \mathrm{cfu} \mathrm{ml}^{-1}$ with the help of spectrophotometer.

\subsubsection{1-Methylcyclopropene (1-MCP) fumigation}

Inoculated apples were kept over a wire gauge in a desiccator and subjected to 1-MCP treatment in the form of pellets (1 $\left.\mu \mathrm{I}^{-1}\right)$ for 12 hours. Following 1-MCP treatment and before boxing, apples were placed on trays and air equilibrated for 6 hours to allow for 1-MCP out gassing the fruit.

\subsubsection{Skin coating}

Essential oil of neem (Azadirachta indica) at 1\% concentration was used as skin coating on inoculated apple fruits. The emulsifier (Tween 20) was added to enhance the solubility of oil suspension.

\subsubsection{Impregnation of fruit trays}

Five botanicals viz. Murraya exotica (Gandla), Dodonaea viscosa (Mehandu), Mentha piperita (Pudina), Emblica officinalis (Amla) and Melia azadirach (Darek) were evaluated as Botanical Formulation (BF) against mouldy core and pink mould rot of apples. BF was prepared by adding equal quantity of the sterilized plant parts and sterilized distilled water $(\mathrm{w} / \mathrm{v})$ and homogenised in a mixer grinder. Impregnation of fruit trays was done by spraying BF (10\%) over 10 fruit trays followed by shade drying. Inoculated apples were placed in BF-impregnated fruit trays and then stored in CA storage.

\subsection{Controlled atmosphere (CA) storage}

The fruits were stored under CA conditions of $1 \pm 0.5^{\circ} \mathrm{C}$ temperature, 87 to $92 \% \mathrm{RH}, 1.4 \%$ carbon dioxide and $1.2 \%$ oxygen concentration for 4 months.

\section{Results and Discussion}

\subsection{Isolation and identification of causal fungi}

The pathogens associated with mouldy core and pink mould rots of apple fruits were repeatedly isolated from infected fruits collected during survey (Figure 1). From the cultural and microscopic examination of the diseased samples (Figure 2), the following causal organisms were identified:

\section{a. Alternaria alternata}

The fungus causing mouldy core of apple was identified as Alternaria alternata. The colony was black in colour. Under microscope, conidiophores were pale brown to olive brown in
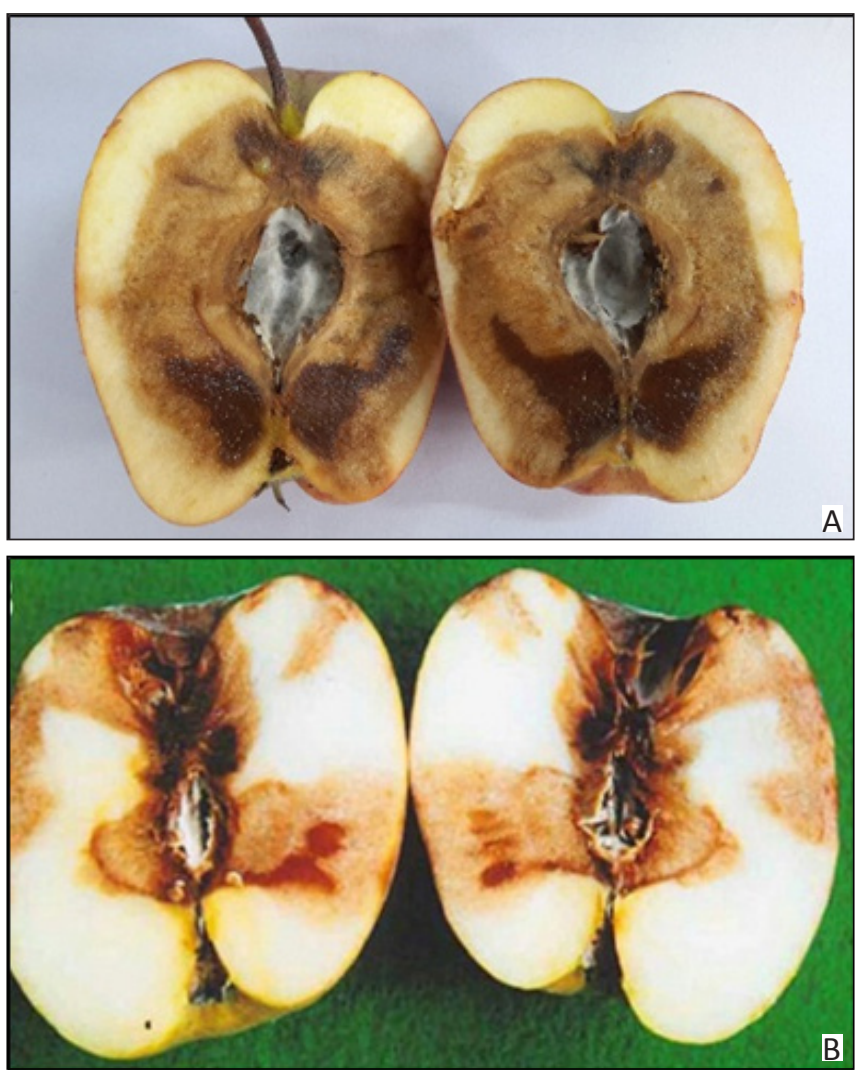

Figure 1: Symptoms of mouldy core rot (A) and pink mould rot (B) on apple fruits
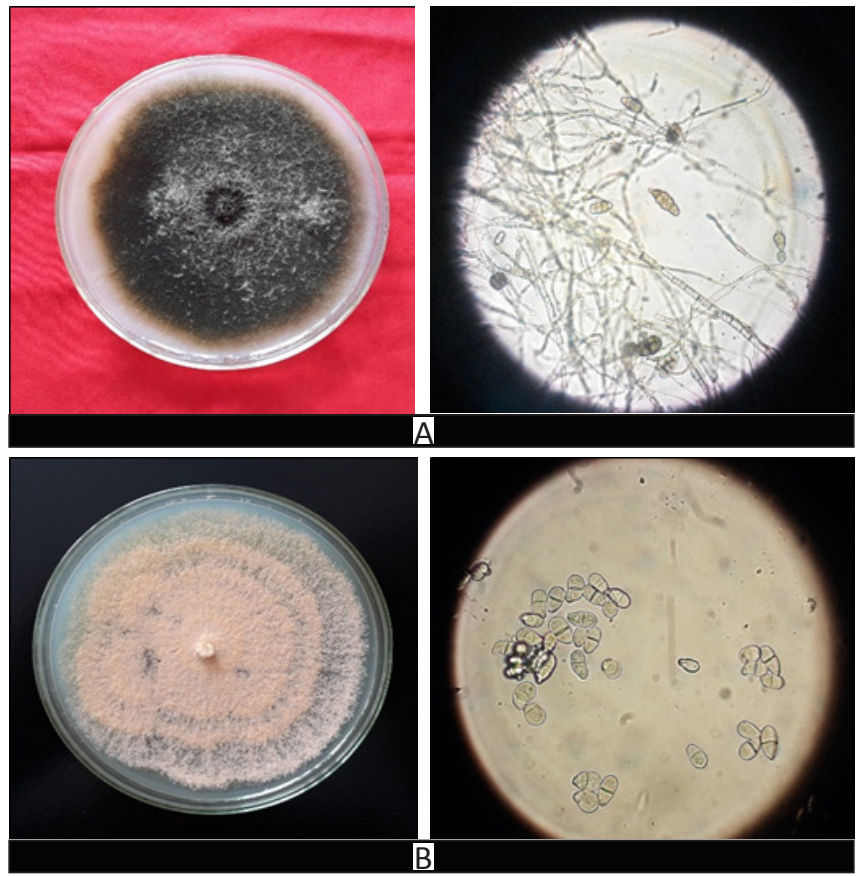

Figure 2: Macroscopic (pure culture) \& microscopic features of Alternaria alternata (A) and Trichothecium roseum (B)

colour, straight or flexuous. Conidia were pale brown to light brown in colour, obclavate to obpyriform in shape, with both vertical and transverse septa, measuring 20-63 ×9-18 $\mu$ in size. 


\section{b. Trichothecium roseum}

The fungus causing pink mould rot was identified as Trichothecium roseum. The mycelium was branched, septate and pinkish coloured in mass but hyaline under microscope. Conidiophores were erect, non-septate, unbranched and swollen at the tips. Conidia were hyaline, acrogenous, single, pear-shaped, two-celled, the apical cell was larger and measured 12-18 $\times$ 8-10 $\mu$ in size.

\subsection{Rot incidence (\%)}

The perusal of data presented in Table 1 revealed that treatment combination $T_{7}$ was the most effective in inhibiting mouldy core and pink mould rots in apples with incidence of 16.05 and $20.46 \%$, respectively as compared to control where $100 \%$ incidence was recorded. Next effective treatment combinations were $\mathrm{T}_{6}$ and $\mathrm{T}_{4}$ with rot incidence of $20.35,23.07$ and $29.47,32.04 \%$, respectively. After control, maximum rot incidence was observed in treatment T1 (75.12 and $81.87 \%$ ) followed by T8 (62.89 and $72.94 \%$ ).

Table 1: Efficacy of different treatments on incidence of mouldy core and pink mould rot of apple fruits under CA storage conditions

\begin{tabular}{lcc}
\hline Treatments & \multicolumn{2}{c}{ Rot incidence (\%) } \\
\cline { 2 - 3 } & $\begin{array}{c}\text { Mouldy } \\
\text { core rot }\end{array}$ & $\begin{array}{c}\text { Pink } \\
\text { mould rot }\end{array}$ \\
\hline HIWC+HWT $\left(50^{\circ} \mathrm{C}\right)\left(\mathrm{T}_{1}\right)$ & 75.12 & 81.87 \\
$\mathrm{~T}_{1}+$ Plant extract $\left(\mathrm{T}_{2}\right)$ & 49.34 & 58.77 \\
$\mathrm{~T}_{1}+$ Antagonist $\left(\mathrm{T}_{3}\right)$ & 41.75 & 51.64 \\
HIWC+Antagonist+1-MCP fumiga- & 29.47 & 32.04 \\
tion $\left(\mathrm{T}_{4}\right)$ & & \\
Skin coating with neem oil (1\%)+BF- & 32.86 & 39.83 \\
impregnated trays $\left(\mathrm{T}_{5}\right)$ & & \\
HIWC+Antagonist+BF-impregnated & 20.35 & 23.07 \\
trays $\left(\mathrm{T}_{6}\right)$ & & \\
HIWC+Skin coating with neem oil & 16.05 & 20.46 \\
(1\%)+BF-impregnated trays $\left(\mathrm{T}_{7}\right)$ & & \\
Apples untreated+BF-impregnated & 62.89 & 72.94 \\
trays ( $\left.\mathrm{T}_{8}\right)$ & & \\
Control $\left(\mathrm{T}_{9}\right)$ & 100 & 100 \\
Mean & 47.54 & 53.40 \\
\hline
\end{tabular}

$\mathrm{CD}(p=0.05)$ Treatment: 0.776 ; Test pathogen: 0.366 ; Treatment $\times$ Test pathogen $=1.097$

\subsection{Fruit rot (\%)}

The perusal of data presented in Table 2 revealed that treatment combination 77 was the most effective in inhibiting mouldy core and pink mould rots in apples with fruit rot of 9.05 and $11.46 \%$. Next effective treatment combinations were T6 and T4 with fruit rot of 13.34, 17.08 and 18.46, 20.03\%, respectively. After control (untreated fruits), maximum fruit
Table 2: Efficacy of different treatments on fruit rot due to mouldy core and pink mould rot of apple under CA storage conditions

\begin{tabular}{|c|c|c|}
\hline \multirow[t]{2}{*}{ Treatments } & \multicolumn{2}{|c|}{ Fruit rot (\%) } \\
\hline & $\begin{array}{l}\text { Mouldy } \\
\text { core rot }\end{array}$ & $\begin{array}{l}\text { Pink } \\
\text { mould rot }\end{array}$ \\
\hline $\mathrm{HIWC}+\mathrm{HWT}\left(50^{\circ} \mathrm{C}\right)\left(\mathrm{T}_{1}\right)$ & 40.11 & 43.34 \\
\hline $\mathrm{T}_{1}+\mathrm{Plant}$ extract $\left(\mathrm{T}_{2}\right)$ & 28.33 & 29.02 \\
\hline $\mathrm{T}_{1}+$ Antagonist $\left(\mathrm{T}_{3}\right)$ & 30.22 & 31.51 \\
\hline $\begin{array}{l}\text { HIWC+Antagonist+1-MCP fumiga- } \\
\text { tion }\left(\mathrm{T}_{4}\right)\end{array}$ & 18.46 & 20.03 \\
\hline $\begin{array}{l}\text { Skin coating with neem oil (1\%)+BF- } \\
\text { impregnated trays }\left(T_{5}\right)\end{array}$ & 22.06 & 22.19 \\
\hline $\begin{array}{l}\text { HIWC+Antagonist+BF-impregnated } \\
\text { trays }\left(\mathrm{T}_{6}\right)\end{array}$ & 13.34 & 17.08 \\
\hline $\begin{array}{l}\text { HIWC+Skin coating with neem oil } \\
(1 \%)+B F-i m p r e g n a t e d \text { trays }\left(T_{7}\right)\end{array}$ & 9.05 & 11.46 \\
\hline $\begin{array}{l}\text { Apples untreated+BF-impregnated } \\
\text { trays }\left(\mathrm{T}_{8}\right)\end{array}$ & 36.93 & 39.12 \\
\hline Control $\left(\mathrm{T}_{9}\right)$ & 100 & 100 \\
\hline Mean & 33.17 & 34.86 \\
\hline
\end{tabular}

rot was observed in fruits treated with treatment combination $\mathrm{T}_{1}$ (40.11 and $43.34 \%$ ) followed by $\mathrm{T}_{8}$ (36.93 and $39.12 \%$ ).

Meena and Mariappan (1993) found that leaf extracts of Azadirachta indica, Mentha arvensis, Aegle marmelos, Catharanthus roseus, Lantana camara, Pongamia pinnata, Vitex negundo and Nerium odorum and flower extracts of C. roseus inhibited mycelial growth of Alternaria tenuis ( $A$. alternata) under in vitro conditions. Xin et al. (2000) used six strains of Bacillus subtilis as a biocontrol agent against core rot fungi such as Alternaria alternata, Trichothecium roseum and Fusarium species. Integrating biocontrol agents with fungicides have been proposed to enhance the efficacy of biocontrol agents (Zhou et al., 2002, 2005). Controlled atmosphere has been found useful to reduce fungal growth, mainly by extending host resistance but also by suppression of fungal pathogens with high $\mathrm{CO}_{2}$ treatments inhibiting various metabolic functions (Qin et al., 2004). The combined treatment of gamma irradiation and fumigation resulted in greater control of $C$. gloeosporioides and $P$. expansum in apple under both ambient $\left(25 \pm 2^{\circ} \mathrm{C}\right)$ and cold $\left(4^{\circ} \mathrm{C}\right)$ storage (Cheon et al., 2016).

\section{Conclusion}

The obtained results in the present study revealed that using neem oil as fruit skin coating on apple fruits pre-cooled using ice water $+\mathrm{CaCl}_{2}$ followed by placing the treated fruits on 
fruit trays impregnated with botanical formulations prior to CA storage resulted in significant reduction in mouldy core rot and pink mould rot of apple fruits artificially inoculated with the test fungi. Under the light of these results, the usage of the proposed formula could be suggested for application against post-harvest decay of apple fruits.

\section{References}

Al-Hindi, R.R., Al-Nazada, A.R., Mohamed, S.A., 2011. Isolation and identification of some fruit spoilage fungi: Screening of plant cell wall degrading enzymes. African Journal of Microbiology Research 5, 443-448.

Cheon, W., Kim, Y.S., Balaraju, K., Kim Bong-Su, Lee ByeongHo, Jeon, Y., 2016. Post harvest disease control of Colletotrichum gloeosporioides and Penicillium expansum on stored apples by gamma irradiation combined with fumigation. Plant Pathology Journal 32, 460-468.

Granger, K., Horne, A.S., 1924. A method of inoculating the apples. Annals of Botany 38, 212-215.

Gupta, D., Sharma, J.N., 2008. Natural occurrence of water core and core rot of apple in Himachal Pradesh (abstract). Indian Phytopathology 61, 386.

Hamid, M.I., Hussain, M., Ghazanfar, M.U., Raza, M., Liu, X.Z., 2014. Trichothecium roseum causes fruit rot of tomato, orange and apple in Pakistan. Plant Disease 98, 1271.

Jurick, W.M., 2014. First report of Alternaria alternata causing post harvest decay on apple fruit during cold storage in Pennsylvania. Plant Disease 98, 690.

Kaul, J.L., 1979. Studies on important post harvest diseases of apple caused by fungi and their control. Ph.D. thesis, Dr. Y. S. Parmar UHF, Nauni, Solan (HP), India, 208.

Kwon, J.H., Kim, M.J., Shim, C.K., Jee, H.J., Lee, S.D., 2014. Pink mould rot on apple (Malus pumila var. dulcissima Koidz.) caused by Trichothecium roseum (Pers.) Link ex Gray in Korea. The Korean Journal of Pesticide Science 18, 429-433.

Marie-Jose, Cote, Marie-Claude, Tardif, Allison, J.M., 2004. Identification of Monilinia fructigena, M. fructicola, $M$. laxa and Monilia polystroma on inoculated and naturally infected fruit using multiplex PCR. Plant Disease 88, 1219-1225.

Martinelli, F.M., Busconi, F., Camangi, C., Fogher, A., Stefani, Sebastiani, L., 2008. Ancient Pomoideae (Malus domestica Borkh. and Pyrus communis L.) cultivars in "Appenino Toscano" (Tuscany, Italy): molecular (SSR) and morphological characterization. Caryologia 61, 320-331.
Meena, S.S., Mariappan, V., 1993. Effect of plant products on seed borne mycoflora of sorghum. Madras Agricultural Journal 83, 383-387.

Niem, J., Miyara, I., Ettedgui, Y., Reuveni, M., Flaishman, M., Prusky, D., 2007. Core rot development in Red Delicious apples is affected by susceptibility of the seed locule to Alternaria alternata colonization. Phytopathology 97, 1415-1421.

Qin, G., Tian, S.P., Xu, Y., 2004. Biocontrol of postharvest diseases on sweet cherries by four antagonistic yeasts in different storage conditions. Postharvest Biology and Technology 31, 51-58.

Reuveni, M., Sheglov, D., 2002. Effects of azoxystrobin, difenoconazole, polyoxin B (polar), and trifloxystrobin on germination and growth of Altemaria alternata and decay in Red Delicious apple fruit. Crop Protection 21, 951-955.

Shtienberg, D., 2012. Effects of host physiology on the development of core rot caused by Alternaria alternata in Red Delicious apples. Phytopathology 102, 769-778.

Srivastava, M.P., Tandon, R.N., 1968. Influence of temperature on Botryodiplodia rot of citrus and sapodilla. Indian Phytopathology 21, 195-197.

Vico, I., Duduk, N., Vasic, M., Nikolic, M., 2014. Identification of Penicillium expansum causing postharvest blue mould decay of apple fruit. Pesticides and Phytomedicine 29, 257-266.

Xin, Y.C., Qin, S.L., Li, B.D., Yin, S.C., Ding, X.H., Lei, C.X., 2000. Control efficacy and inhibitory action of Bacillus subtilis XM16 strain on disease and pathogens of apple mould core. Acta Phytopalhologica Sinica 30, 66-70.

Zhou, T., Northover, J., Schneider, K.E., Lu, X., 2002. Interactions between Pseudomonas syringae MA-4 and cyprodinil in the control of blue mould and grey mould of apple. Canadian Journal of Plant Pathology 24, 154-161.

Zhou, T., Yu, H., Errampalli, D., 2005. Strategies for biological control of fungal diseases of temperate fruits. In: Chincholkar, S.B.(Ed.), Management of Fruit and Vegetable Diseases, vol. IV, Biological Control. Kluwer Academic, Netherlands. 